\title{
The mitogen-activated protein kinase pathway tonically inhibits both basal and IGF-I-stimulated IGF-binding protein-5 production in mammary epithelial cells
}

\author{
Jodie M Fleming, Jeffrey A Brandimarto and Wendie S Cohick \\ Rutgers, The State University of New Jersey, 108 Foran Hall, 59 Dudley Road, New Brunswick, New Jersey 08901-8520, USA \\ (Correspondence should be addressed to W S Cohick; Email: cohick@aesop.rutgers.edu) \\ J M Fleming is now at Center for Cancer Research, NCI Building 37 Room 1108, 37 Convent Drive, Bethesda, Maryland 20892-4254, USA
}

\begin{abstract}
The IGF system plays a key role in mammary gland growth and development. Our lab previously reported that IGF-I primarily regulates IGF-binding protein (BP)-3 in bovine mammary epithelial cells (MEC) and IGFBP-5 in mammary fibroblasts (MF). Presently, we examined the signaling pathways used by IGF-I to elicit this distinct, cell-type specific regulation. The phosphatidylinositol-3 kinase pathway was required for IGF-I to increase IGFBP-3 and 5 in MF and IGFBP-3 in MEC. Surprisingly, inhibiting the mitogen-activated protein kinase (MAPK) pathway in MEC increased IGFBP-5 mRNA levels 2- to 4-fold under basal conditions and 8- to 12 -fold in cells treated with IGF-I within $4 \mathrm{~h}$. Similar patterns of IGFBP-3 and -5 regulation were observed in murine MEC. Cells treated with IGF-I in the presence of MAPK inhibitors secreted more IGFBP-5 protein into conditioned media relative to cells treated with IGF-I
\end{abstract}

alone; however, IGFBP-5 protein was not detected in conditioned media of cells treated with only a MAPK inhibitor. The IGFBP-5 mRNA response to MAPK inhibitors was specific for MEC, as blocking MAPK activity decreased the ability of IGF-I to induce IGFBP-5 in MF. In addition, no other IGFBP was increased in either cell type when MAPK activity was inhibited. These increases in IGFBP-5 expression in response to inhibition of the MAPK pathway corresponded with the induction of apoptosis. In conclusion, we report the novel observation that the MAPK/extracellular signal regulated kinase (ERK) pathway specifically represses IGFBP-5 expression in MEC. The corresponding changes in apoptosis and IGFBP-5 expression support a role for this specific IGFBP in mammary gland involution.

Journal of Endocrinology (2007) 194, 349-359

\section{Introduction}

The mammary gland is a complex organ, composed of secretory epithelium and diverse cells of the supportive stroma. This network of cells intricately communicates to control numerous cycles of mammary growth, differentiation, lactation, and involution. The insulin-like growth factor (IGF) system regulates numerous cellular functions that underlie these processes, including mitogenesis and survival. The ability of IGF-I to regulate biological activity in mammary cells is regulated by six high-affinity binding proteins (IGFBP-1 through -6). mRNA for all six IGFBP has been detected in mammary tissue of several species and, similar to IGF-I, their expression patterns and relative levels vary considerably between stages of development (Wood et al. 2000, Plath-Gabler et al. 2001, Flint et al. 2005). The distinct expression pattern of each of the IGFBP during different stages of mammary development suggests specialized roles, although data on the specific functions of the individual IGFBP in normal development of the mammary gland are limited.
Moreover, even less data are available on how such distinctive, cell-type specific regulation occurs.

A positive relationship between IGFBP-5 expression and mammary cell death during the process of lactational involution has been reported in multiple species (Tonner et al. 1995, 1997, Boutinaud et al. 2004, Flint et al. 2005). In contrast, several reports have suggested that IGFBP-5 is not exclusively pro-apoptotic in mammary cells. For example, IGFBP-5 mRNA has been detected in terminal end bud structures during postnatal mammary gland development and in ductal and alveolar epithelial cells from mid-pregnant mouse mammary glands (Allar \& Wood 2004). Additionally, the expression of IGFBP-5 was significantly upregulated following hormone-induced differentiation of murine mammary epithelial cells (MEC) cultures (Phillips et al. 2003, Boutinaud et al. 2004, Lochrie et al. 2006). The potential multi-functionality of IGFBP-5 may have important consequences for the life cycle of the MEC, and it has been hypothesized that the ratio of IGFBP-5:IGF-I may be critical 
in the control of IGF action and ultimately, cell fate (Lochrie et al. 2006).

IGF-I elicits its effects by binding to the IGF-I receptor (IGF-IR), triggering receptor auto-phosphorylation and subsequent activation of downstream signaling pathways. The two classical signal transduction pathways activated by IGF-I are the phosphatidylinositol-3 kinase (PI3K) and mitogen-activated protein kinase (MAPK) pathways. Recent studies from our group have shown that both of these pathways are involved in regulation of IGFBP-3 expression in MEC (Sivaprasad et al. 2004). Furthermore, we have shown that IGF-I primarily regulates IGFBP-3 in MEC and IGFBP-5 in mammary fibroblasts (MF; Fleming et al. 2005). In the present study, we further examined the distinct, cell-type specific regulation of these two IGFBP by IGF-I via analysis of intracellular signaling pathways.

In the present study, we found that both the PI3K and the MAPK pathways were required for IGF-I to increase IGFBP-3 and -5 in MF. However, an unexpected and novel finding was that the MAPK pathway inhibited basal IGFBP-5 expression in MEC. Furthermore, pretreatment of cells with MAP kinase kinase (MEK) inhibitors prior to IGF-I treatment enhanced the ability of IGF-I to increase IGFBP-5 expression. These findings suggest that the MAPK pathway exerts a tonic inhibition on both basal and IGF-I-stimulated IGFBP-5 expression. This regulation is specific for MEC and IGFBP-5, as blocking MEK activity decreased IGFBP-5 expression in MF and IGFBP-3 was downregulated by inhibition of MEK in both cell types. Since the MAPK pathway is associated with cell proliferation and is often upregulated in breast cancer cells, it seems logical that it may act to repress IGFBP-5, which normally acts as a growth inhibitor. To date no such mechanism has been shown for regulation of IGFBP expression by IGF-I.

\section{Materials and Methods}

\section{Reagents}

Recombinant human IGF-I and LongR3 IGF-I were obtained from GroPep (North Adelaide, Australia). B-chain IGF-I mutant (B-IGF-I) was kindly provided by Dr Margaret Cascieri (Merck). Cell culture reagents were from Invitrogen Co. with the exception of fetal bovine serum (Gemini Bio-Products; Woodland, CA, USA), phenol-red free Dulbecco's Modified Eagle's Medium (DMEM, SigmaAldrich), and charcoal-stripped fetal bovine serum (FBS; Omega Scientific, Tarzana, CA, USA). Tissue culture plasticware was from Becton-Dickinson (Franklin Lakes, NJ, USA). Bovine insulin and D-glucose were from SigmaAldrich. Antibody against the phosphorylated form of Akt $\left(\mathrm{Ser}^{473}\right)$ was purchased from Cell Signaling Technology (Beverly, MA, USA). An antibody against phosphorylated ERK 1/2 was purchased from Santa Cruz Biotechnology (Santa Cruz, CA, USA). Antibodies that recognize total ERK
1/2 and AKT were purchased from Upstate Biotechnology Inc. (Lake Placid, NY, USA). MAPK inhibitors PD98059 and U0126, the PI3K inhibitor LY294002, the P38 inhibitor SB203580, and the JNK inhibitor SP600125 were purchased from Calbiochem (La Jolla, CA, USA), resuspended as $10 \mathrm{mM}$ stock solutions in dimethyl sulfoxide, and stored at $-20{ }^{\circ} \mathrm{C}$.

\section{Cell culture experiments}

The bovine MEC line, MAC-T, was established from primary bovine MEC by immortalization with the SV40 large-T antigen (Huynh et al. 1991). Primary MEC and MF were isolated from lactating cows as previously described (Fleming et al. 2005). The murine mammary cell NMuMG (CRL1636) was obtained from American Type Culture Collection (ATCC; Manassas, VA, USA). Stock cultures of MAC-T, NMuMG, and primary MEC were maintained in phenolred-containing DMEM supplemented with $4.5 \mathrm{~g} / 1$ D-glucose, $10 \% \mathrm{FBS}, 5 \mu \mathrm{g} / \mathrm{ml}$ bovine insulin, $20 \mathrm{U} / \mathrm{ml}$ penicillin, $20 \mu \mathrm{g} / \mathrm{ml}$ streptomycin, and $50 \mu \mathrm{g} / \mathrm{ml}$ gentamicin (complete media), at $37^{\circ} \mathrm{C}$ in a humidified atmosphere with $5 \% \mathrm{CO}_{2}$. Stock cultures of MF were maintained in complete media with $0.5 \mu \mathrm{g} / \mathrm{ml}$ amphotericin $\mathrm{B}$, without phenol-red or insulin supplementation.

For all experiments, cells were plated in complete media without insulin or phenol-red. MF were grown to near confluence, rinsed with phenol-red-free serum-free (PRFSF) DMEM, and incubated in DMEM containing 10\% charcoalstripped FBS and antibiotics for $24 \mathrm{~h}$. The cells were then rinsed and incubated in PRFSF DMEM with $0 \cdot 2 \%$ BSA and $30 \mathrm{nM} \mathrm{Na}$ selenite. After $24 \mathrm{~h}$, spent media were aspirated and replaced with PRFSF DMEM without additives \pm treatments. MAC-T, NMuMG, and primary MEC were treated similarly to MF, but without the 24-h incubation in charcoal stripped FBS-containing media. For RNA analysis, cells were lysed in Trizol (Invitrogen Co.) and stored at $-80{ }^{\circ} \mathrm{C}$ until analysis. For analysis of secreted IGFBP, conditioned media were collected, cleared by centrifugation, and stored at $-20{ }^{\circ} \mathrm{C}$ until analysis.

\section{Western ligand blotting}

The total protein content of conditioned media was determined using the Bradford protein assay kit (Bio-Rad Laboratories). Conditioned media containing equal amounts of protein were separated by SDS-PAGE under non-reducing conditions, as previously described (Cohick \& Turner 1998). Briefly, the proteins were transferred to nitrocellulose membranes, incubated overnight with $\left[{ }^{125} \mathrm{I}\right]-\mathrm{IGF}-\mathrm{I}$ (Amersham Biosciences), washed, and then exposed to PhosphorImager Screens. Differences in relative band intensities were determined by PhosphorImager analysis (Molecular Dynamics, Inc., Sunnyvale, CA, USA). 


\section{Western immunoblotting}

Cell lysates were isolated as previously described (Grill et al. 2002) and total protein content of the cytosolic fraction was determined using the Bradford protein assay kit (Bio-Rad Laboratories). Equal amounts of protein were separated by SDS-PAGE under reducing conditions, as previously described (Grill et al. 2002). Membranes were blocked in 5\% non-fat dried milk for $1 \mathrm{~h}$ at room temperature, incubated with primary antibody overnight at $4{ }^{\circ} \mathrm{C}$, washed, and incubated with the appropriate secondary antibody conjugated to horseradish peroxidase (Amersham). After washing, the peroxidase activity was detected using the enhanced chemiluminescence detection system (ECL Plus, Amersham) according to the manufacturer's recommendations.

\section{Northern blot analysis}

Total RNA was isolated and analyzed by northern blotting as described previously (Cohick et al. 2000). Briefly, denatured RNA $(10 \mu \mathrm{g} / \mathrm{lane})$ was separated by electrophoresis, transferred to nylon membranes (Biotrans, ICN; Irvine, CA, USA), and then hybridized overnight with $\left[{ }^{32} \mathrm{P}\right]-\mathrm{dCTP}$ labeled cDNA probes for bovine IGFBP-3, human IGFBP-5, GAPDH, or $18 \mathrm{~S}$ rRNA. Membranes were washed, exposed to PhosphorImager Screens, and the differences in relative band intensities were determined by PhosphorImager analysis (Molecular Dynamics Inc).

\section{Reverse transcription and quantitative real-time PCR}

Unless otherwise stated, all reagents were purchased from Applied Biosystems (Foster City, CA, USA). RNA was isolated using the RNeasy isolation kit according to the manufacturer's instructions (Qiagen Inc). RNA quality was verified by inspection of the $18 \mathrm{~S}$ and $28 \mathrm{~S}$ rRNA bands after agarose gel electrophoresis. RNA $(2 \mu \mathrm{g})$ was reverse transcribed according to manufacturer's instructions using random primers and MultiScribe Reverse Transcriptase. A pool of undiluted cDNA was used to create a standard curve with serial dilutions of 1:2, 1:20, 1:200, and 1:2000, for determination of relative gene expression. To determine gene expression profiles, individual samples were diluted 1:4; $9 \cdot 5 \mu \mathrm{l}$ diluted sample was amplified in a $27 \cdot 5-\mu$ l reaction mix containing $10 \cdot 5 \mu \mathrm{l}$ Power SYBR Green qPCR MasterMix, $6.5 \mu \mathrm{l} \mathrm{dH_{2 }}$ O, and $0.5 \mu \mathrm{l}(\sim 200 \mu \mathrm{M})$ each forward and reverse gene-specific primer. The IGFBP-3 primer set was obtained from Voge et al. (2004). Primer sets for bovine cyclophilin were F $5^{\prime}$-GAG CAC TGG AGA GAA AGG ATT TGG-3'; R 5'-TGA AGT CAC CAC CCT GGC ACA TAA-3', IGFBP-5 F 5'-GCA AGC CAA GAT CGA AAG AG-3'; R 5'- GAA GAT CTT GGG CGA GTA GG3', IGFBP-4 F 5'-ACT CGG GGA CCT CTA CCA CT; R $5^{\prime}$-AGC ACG GAG TCC AGA TGT T-3', and IGFBP-6 F 5'-GAC AAG GCG TGT GCA TGG; R 5'-AGG GGC TGA AGC TGT TGT T- $3^{\prime}$, and were developed using
PrimerQuest (IDT, Coralville, IA, USA). Fluorescent PCR products were detected in single wells of a 96-well plate (TKR Biotech, Huntingdon Valley, PA, USA) using an Applied Biosystems 7300 Real-Time PCR System. Fluorescence was measured following each cycle and displayed graphically (Applied Biosystems 7300/7500 SDS Software, version 1.3.1, ABI, Foster City, CA, USA), and mean expression relative to untreated samples was determined. Data are reported as values normalized to cyclophilin. The software determined a cycle threshold value, which identified the first cycle at which the fluorescence was detected above the baseline for that sample or standard. Products were verified by agarose gel electrophoresis. Melting curves were generated for each sample.

\section{Cell death detection ELISA}

Cell death was measured using the cell death detection ELISA $^{\text {plus }}$ from Roche, according to the manufacturer's recommendations. This assay is designed to detect histoneassociated DNA fragments (mono- and oligonucleosomes) generated by apoptotic cells.

\section{Statistical analysis}

Data were analyzed by ANOVA with differences considered significant where $P<0 \cdot 05$. Post hoc analyses included Tukey's, Bonferroni $t$-test, and Dunn's method where appropriate. Analyses were performed in SigmaStat (2.03) program for Windows (SPSS Inc., Chicago, IL, USA).

\section{Results}

Treatment with IGF-I increases IGFBP-3 and $-5 \mathrm{mRN} A$ levels in MAC-T cells

In the bovine MEC line, MAC-T, IGF-I induced a small but consistent 2-fold increase in IGFBP-5 mRNA levels as opposed to a robust increase of 8 - to 12-fold in IGFBP-3 mRNA levels $(P<0 \cdot 02$; Fig. 1$)$. While the magnitude of the response was much greater for IGFBP-3, the time course of induction was similar for the two IGFBP (Fig. 1).

\section{The PI3K pathway is required for IGF-I-stimulated IGFBP-5 $m R N A$ levels in MAC-T cells}

In order to determine the role of the PI3K-signaling pathway in the regulation of IGFBP-5 expression, cells were pretreated with LY 294002 (LY), a specific chemical inhibitor of the PI3K pathway. A concentration of $20 \mu \mathrm{M}$ LY effectively decreased Akt activation in IGF-I-treated cells (Fig. 2A). Similar to our previous findings with IGFBP-3 mRNA (Sivaprasad et al. 2004), pretreatment with LY significantly inhibited the ability of IGF-I to stimulate IGFBP-5 expression above serum free levels $(P<0 \cdot 02$; Fig. $3 \mathrm{~A}$ and $\mathrm{B})$. 
A
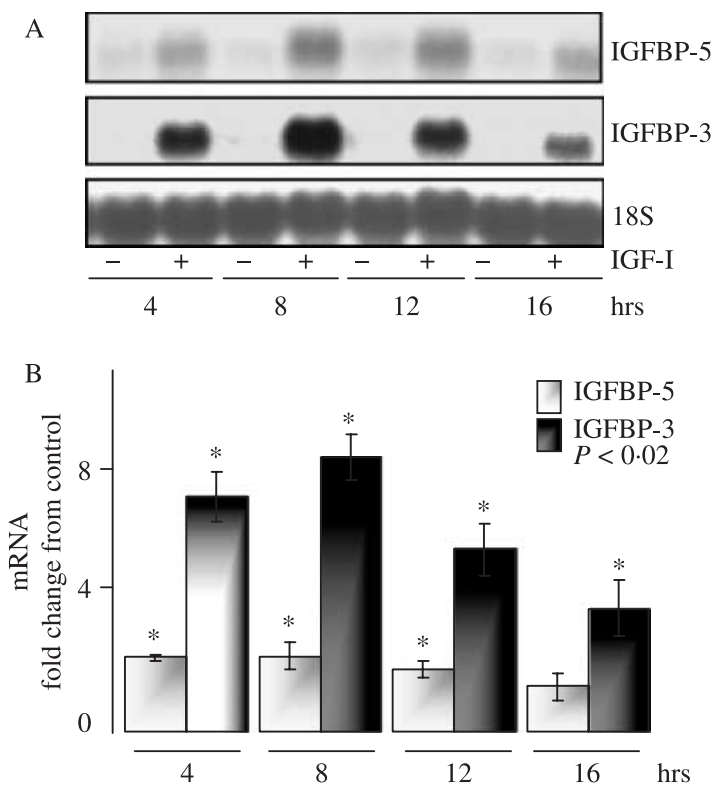

Figure 1 IGF-I induces IGFBP-5 and -3 mRNA levels in mammary epithelial cells. Confluent MAC-T cells were serum starved for $24 \mathrm{~h}$ before addition of fresh serum-free media \pm IGF-I $(100 \mathrm{ng} / \mathrm{ml})$ for indicated times. Total RNA was isolated and analyzed by northern blotting by hybridizing with ${ }^{32}$ P-labeled bovine IGFBP-3, human IGFBP-5, and 185 cDNA. (A) Representative northern blot. (B) Relative intensity by Phosphorlmager analysis: data represent mean \pm s.E.M. of at least three separate experiments. ${ }^{*}$ Indicates significant increase above serum-free levels $(P<0 \cdot 02)$.

The MAPK/ERK pathway tonically represses basal and IGF-Istimulated IGFBP-5 $m R N A$ levels in MAC-T cells

While IGF-I does not stimulate discernible activation of ERK $1 / 2$ in MAC-T cells, we have reported that blocking basal levels of phosphorylated ERK $1 / 2$ attenuates the ability of IGF-I to increase IGFBP-3 mRNA levels (Sivaprasad et al. 2004). Therefore, the MAPK inhibitor PD 98059 (PD) was used to investigate the role of the MAPK pathway in IGFBP-5 expression. As shown in Fig. 2B, $20 \mu \mathrm{M}$ PD effectively inhibited phosphorylation of ERK 1/2 in both untreated and IGF-I-treated cells. Interestingly, after $8 \mathrm{~h}$ of treatment, inhibition of the MAPK pathway increased basal IGFBP-5 mRNA levels approximately two- to fourfold above serumfree levels (Figs 3D, 4B and 5). Furthermore, when the MAPK pathway was blocked, IGF-I increased IGFBP-5 mRNA levels $\sim 8$ - to 12 -fold. Similar increases were observed with a second MAPK inhibitor, U0126 (Fig. 3D). These increases were not due to a compensatory increase in Akt activation, since Akt phosphorylation was not altered in cells exposed to PD (Fig. 2B). Similar results were obtained through 90 min of treatment (data not shown). The ability of inhibitors of the MAPK pathway to increase IGFBP-5 expression in MAC-T cells was specific for this IGFBP, as mRNA levels of IGFBP-2, $-3,-4$ or -6 were not increased by
A

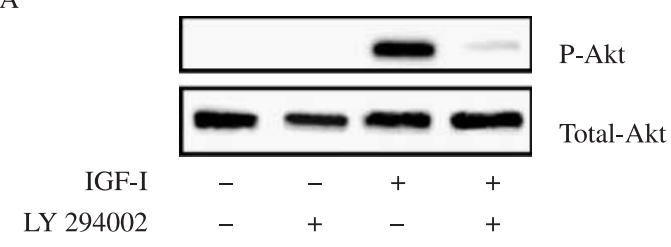

B

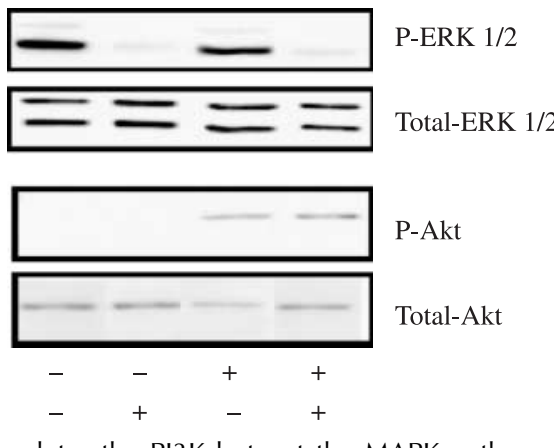

Figure 2 IGF-I regulates the PI3K but not the MAPK pathway in mammary epithelial cells. Confluent MAC-T cells were serum starved for $24 \mathrm{~h}$, pretreated for $30 \mathrm{~min}$ in serum-free media with $20 \mu \mathrm{M}$ of either a specific PI3K inhibitor (LY294002) or MAPK inhibitor (PD98059), then treated \pm IGF-I $(100 \mathrm{ng} / \mathrm{ml})$ for $5 \mathrm{~min}$. Total cell lysates $(20 \mu \mathrm{g})$ were resolved by SDS-PAGE and immunoblotted with antibodies specific for phosphorylated AKT or ERK 1/2. Membranes were stripped and re-probed with antibodies that detect total AKT or ERK 1/2. Representative blots of at least three separate experiments are shown.

PD with or without IGF-I (Fig. 3C and E). In fact, as shown in Fig. 3E, treatment with PD significantly decreased basal expression of IGFBP-2 and -4 mRNA levels, while having no effect on IGFBP-6 expression.

Time course analysis showed that the increases in IGFBP5 mRNA in response to PD or IGF-I plus PD were rapid and detected within $1 \mathrm{~h}$ of inhibition of the MAPK pathway (Fig. 4A). Changes in IGFBP-5 mRNA were initially analyzed via northern blotting; however, additional experiments were conducted using quantitative real-time PCR (qRTPCR) to more specifically quantitate the magnitude of the changes given the very low basal expression of IGFBP-5 (Fig. 4B). By this analysis, the increase in IGFBP-5 mRNA observed at each time point was greater in response to $\mathrm{PD}$ relative to IGF-I (Fig. 4B). The further increase in message levels observed with the combination of IGF-I and PD was most pronounced at 8,12 , and $16 \mathrm{~h}$. Cells were also treated with inhibitors of the P38 and JNK MAPK pathways to ensure that increases in IGFBP-5 mRNA levels were due to inhibition of the MAPK/ERK cascade and not other MAPK cascades. In contrast to the effects observed with the MAPK/ ERK inhibitors, treatment with inhibitors of either the P38 (SB203580) or the JNK (SP600125) pathways \pm IGF-I had no discernable effect on IGFBP-5 mRNA levels (data not shown). 
A

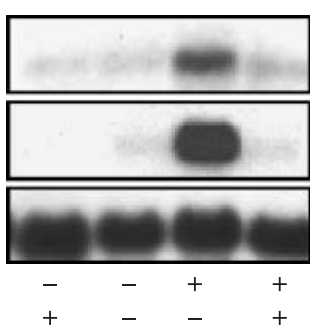

IGFBP-5

IGFBP-3

$18 \mathrm{~S}$

IGF-I

LY294002
B

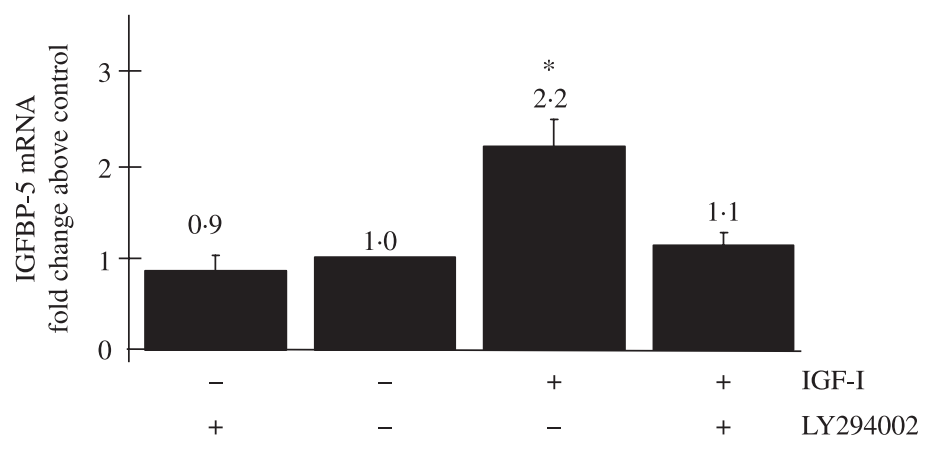

$\mathrm{D}$

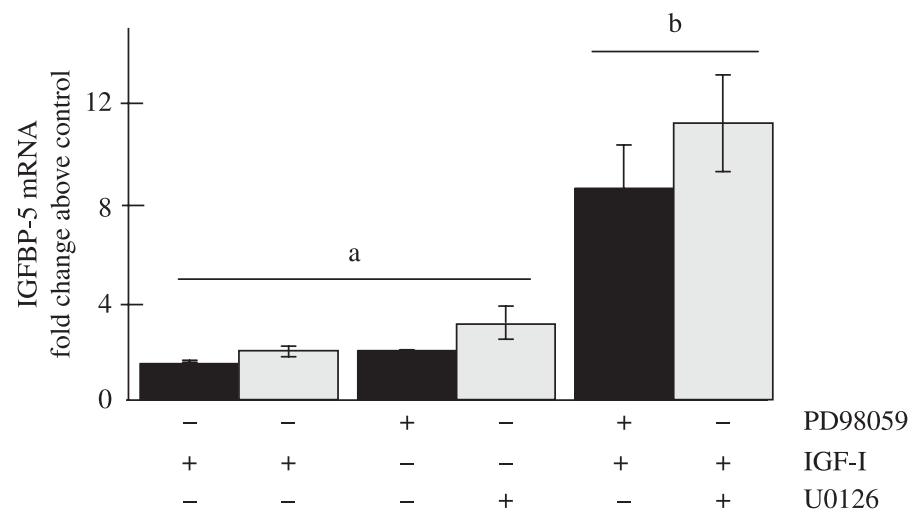

E IGFBP-5

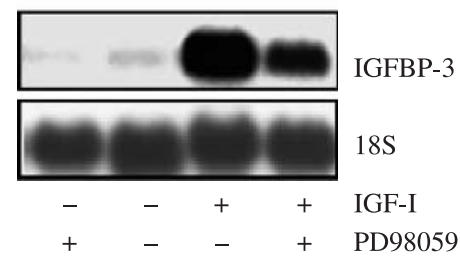

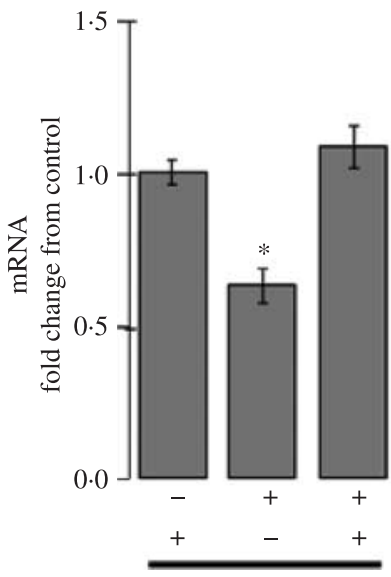

IGFBP-2

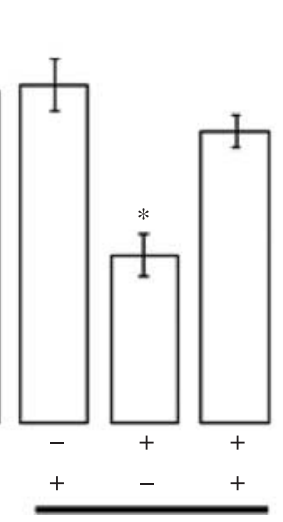

IGFBP-4

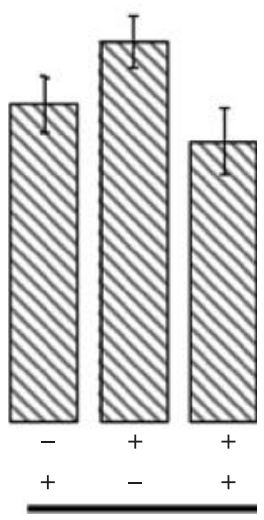

PD98059 IGF-I

Figure 3 The MAPK and PI3K pathways differentially regulate basal and IGF-I-stimulated IGFBP-5 mRNA levels in mammary epithelial cells. Confluent MAC-T cells were serum starved for $24 \mathrm{~h}$, pretreated for $30 \mathrm{~min}$ in serum-free media with either a specific PI3K inhibitor (LY294002) or MAPK inhibitor (PD98059; $20 \mu \mathrm{M}$ or U0126; $5 \mu \mathrm{M}$ ), then treated \pm IGF-I $(100 \mathrm{ng} / \mathrm{ml})$ for $8 \mathrm{~h}$. Total RNA was isolated and then analyzed via northern blotting by hybridizing with ${ }^{32} \mathrm{P}$-labeled human IGFBP-5, bovine IGFBP-3, and 18S cDNA. (A and C) Representative northern blots. (B and D) Relative intensity by Phosphorlmager analysis. Controls represent cells treated with serum-free media. (B) Bars represent mean \pm S.E.M. of eight separate experiments. *Indicates significant increase above serum-free controls $(P<0 \cdot 05)$. (D) Solid bars represent the mean \pm S.E.M. of four experiments in which PD98059 was tested and shaded bars represent the mean \pm s.E.M. of four experiments in which U0126 was tested. Bars with different superscripts are significantly different $(P<0 \cdot 02)$. (E) IGFBP-2 was determined by northern analysis and corrected for 185 , while IGFBP-4 and -6 were analyzed by qRTPCR normalized to cyclophilin. *Indicates significant decrease from serum-free control $(P<0 \cdot 05)$. 
A

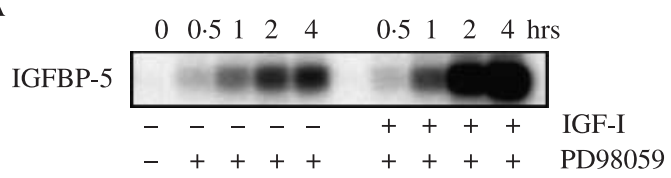

B

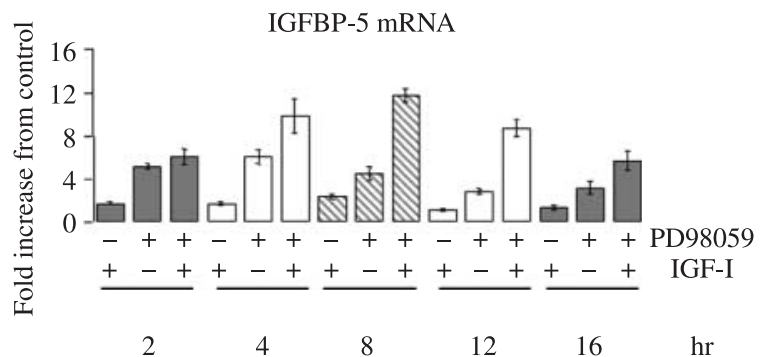

Figure 4 Temporal induction of IGFBP-5 mRNA levels in mammary epithelial cells. Confluent MAC-T cells were serum starved for 24 h, and then treated in serum-free media with a specific MAPK

inhibitor, PD98059 $(20 \mu \mathrm{M}) \pm \mathrm{IGF}-\mathrm{I}(100 \mathrm{ng} / \mathrm{ml})$ for indicated times. Total RNA was isolated and analyzed by (A) northern blotting by hybridizing with ${ }^{32}$ P-labeled human IGFBP-5 and (B) quantitative RTPCR as described in Materials and Methods. Graph represents mean \pm s.E.M. of four separate experiments.

The increase in IGFBP-5 expression observed when the MAPK pathway is repressed is mediated through the IGF-I receptor

Since the ability of IGF-I to increase IGFBP-3 is attenuated when the MAPK pathway is blocked, there could potentially be more free IGF-I available to increase IGFBP-5 expression. To investigate this possibility, experiments were conducted with IGF-I analogs that have normal affinity for the IGF-I receptor, but low affinity for IGFBPs. Results obtained with two different IGF-I analogs were comparable with those obtained with native IGF-I, suggesting that this regulation is mediated through the IGF-I receptor (Fig. 5).

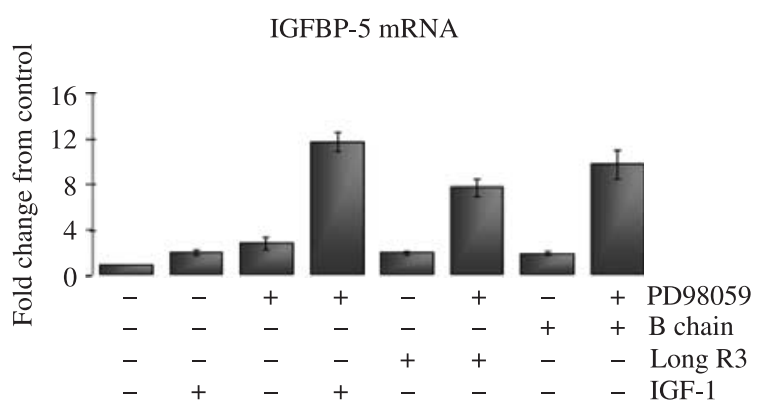

Figure 5 The ability of IGF-I to increase IGFBP-5 expression in mammary epithelial cells treated with MAPK inhibitors is an IGF-I receptor-mediated event. Confluent MAC-T cells were serum starved for $24 \mathrm{~h}$, then treated in serum-free media with a specific MAPK inhibitor, PD98059 $(20 \mu \mathrm{M}) \pm I G F-I$, B-chain IGF-I, or long R3 IGF-I $(100 \mathrm{ng} / \mathrm{ml})$ for $8 \mathrm{~h}$. Total RNA was isolated and analyzed by quantitative RTPCR as described in Materials and Methods. Graph represents mean \pm s.E.M. of three separate experiments.
The MAPK/ERK pathway tonically represses the ability of IGF-I to stimulate IGFBP-5 $\mathrm{mRNA}$ levels in primary bovine $M E C$

The inhibitor studies were repeated in primary MEC to ensure that the observed effect of MAPK inhibition on IGFBP-5 expression was not due to immortalization of the MAC-T cells. We have previously reported that IGFBP-5 mRNA levels were not detectable by northern blot analysis in basal and IGF-I-stimulated primary MEC, and that the more sensitive qRTPCR analysis was required to detect IGFBP-5 mRNA in both control and IGF-I-stimulated cells (Fleming et al. 2005). Therefore, it was not surprising that IGFBP-5 mRNA was difficult to detect in cells treated with IGF-I or an inhibitor of the MAPK pathway by northern blot analysis. However, treatment with the combination of IGF-I and an inhibitor of the MAPK pathway resulted in a striking increase in IGFBP-5 mRNA levels that was easily detectable, even by northern blot analysis (Fig. 6).

Inhibition of the MAPK/ERK pathway enhances the ability of IGF-I to stimulate IGFBP-5 protein levels

To determine whether the robust increases observed in mRNA levels corresponded with an increase in IGFBP-5 protein, conditioned media were analyzed by western ligand blotting. As shown in Fig. 7, IGFBP-5 protein was detectable in media conditioned by cells stimulated with IGF-I. Interestingly, IGFBP-5 was not detectable in the conditioned media from cells treated with the MAPK inhibitor alone. The strongest band intensity was detected in the media from cells treated with the combination of IGF-I and the MAPK inhibitor. The opposite effect was observed with IGFBP-2, -3 , and -4 , i.e. treatment with IGF-I tended to increase these IGFBP, while the combination of IGF-I and PD decreased their detectable levels (Fig. 7).

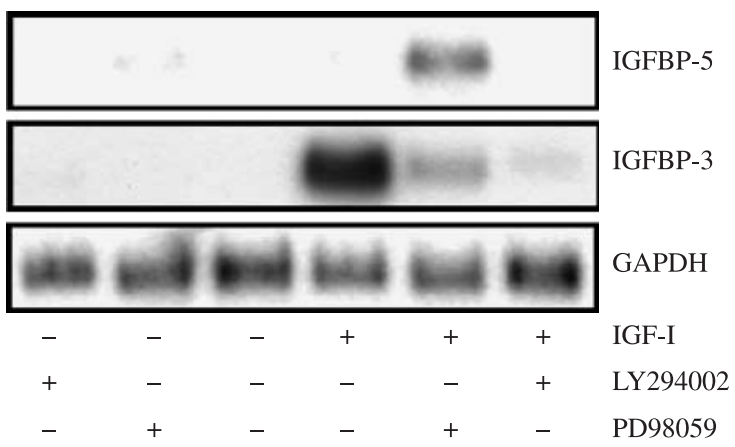

Figure 6 Inhibition of the MAPK pathway induces basal and IGF-Istimulated IGFBP-5 mRNA levels in primary mammary epithelial cells. Confluent cells were serum starved for $24 \mathrm{~h}$, pretreated for 30 min in serum-free media with a MAPK inhibitor (PD98059; $20 \mu \mathrm{M}$ ) or PI3K inhibitor (LY294002; $20 \mu \mathrm{M}$ ) then exposed \pm IGF-I $(100 \mathrm{ng} / \mathrm{ml})$ for $8 \mathrm{~h}$. Total RNA was isolated and analyzed by northern blotting by hybridizing with ${ }^{32}$ P-labeled human IGFBP-5, bovine IGFBP-3, and GAPDH cDNA. A representative northern blot of three separate experiments is shown. 


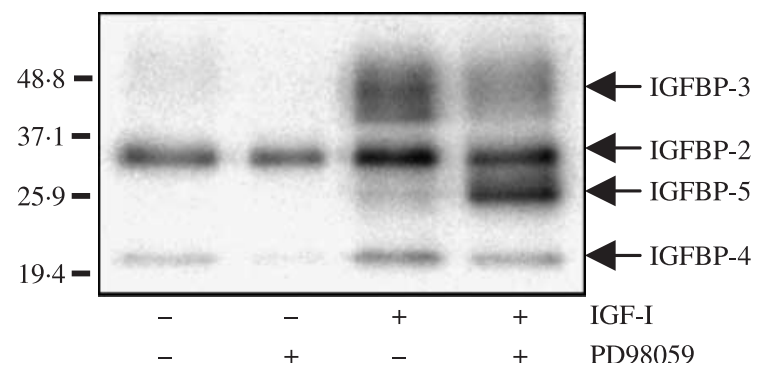

Figure 7 Inhibition of the MAPK pathway increases IGF-Istimulated IGFBP-5 protein secretion in mammary epithelial cells. Confluent MAC-T cells were serum starved for $24 \mathrm{~h}$, pretreated for $30 \mathrm{~min}$ in serum-free media with PD98059 $(20 \mu \mathrm{M})$, then treated \pm IGF-I $(100 \mathrm{ng} / \mathrm{ml})$ for $48 \mathrm{~h}$. Conditioned media containing equal amounts of protein were separated by SDS-PAGE. Following transfer, the membranes were ligand blotted with [ $\left.{ }^{125} I\right]-I G F-I$. Results are representative of three separate experiments. We have previously determined the identity of each IGFBP by immunoblot analysis (Fleming et al. 2005).

The PI3K and MAPK/ERK pathways are required for IGF-Istimulated increases in IGFBP-3 and $-5 m R N A$ levels in $M F$

To examine whether this unique repression of IGFBP-5 by the MAPK pathway was observed in other mammary cell types, we investigated the role of the MAPK and PI3K pathways in regulating IGFBP-3 and -5 expression in primary MF. Our lab has previously reported that IGF-I stimulated two- and fivefold increases in IGFBP-3 and -5 mRNA levels respectively in these cells (Fleming et al. 2005). As shown in Fig. 8A, IGF-I activated the PI3K and MAPK pathway in MF within $5 \mathrm{~min}$. This is in contrast to MAC-T cells, where IGF-I only activates the PI3K pathway. Pretreatment with a $20 \mu \mathrm{M}$ concentration of specific inhibitors of the PI3K and MAPK pathways was sufficient to block the ability of IGF-I to activate these pathways. IGF-I activated Akt similarly in cells treated with or without PD at $5 \mathrm{~min}$ (Fig. 8A).

In MF, inhibition of either the MAPK or the PI3K pathway resulted in a slight, consistent decrease in basal levels of both IGFBP-3 and -5 below serum-free levels. Furthermore, inhibition of either pathway significantly decreased the ability of IGF-I to increase IGFBP-3 and -5 mRNA levels, resulting in mRNA levels that were not significantly different from those observed under serum-free conditions $(P<0 \cdot 002$; Fig. 8B). Similar to MAC-T cells, no increases in IGFBP-2, -4 , or -6 were observed when the MAPK pathway was blocked in MF cells (data not shown). Thus, the repression of an IGFBP by the MAPK pathway was exclusive to IGFBP-5 in MEC.

Regulation of IGFBP-3 and $-5 \mathrm{mRNA}$ levels by IGF-I and the $M A P K / E R K$ pathway are similar for murine mammary epithelial and MAC-T cells

In order to determine if the repression of IGFBP- 5 by the MAPK/ERK pathway was species specific, similar studies were conducted in the normal murine MEC line NMuMG.
A

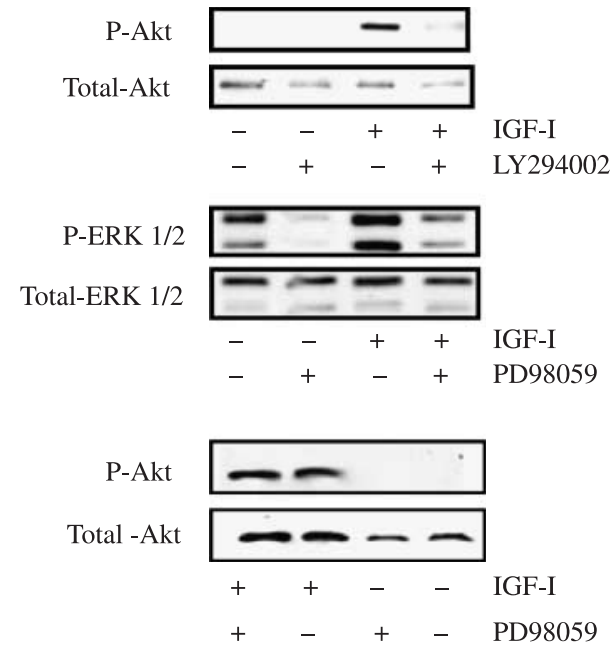

B

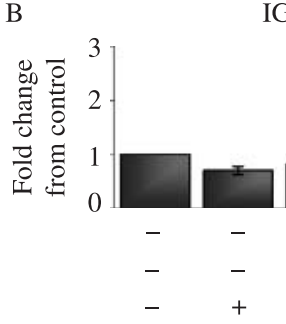

IGFBP-3 mRNA

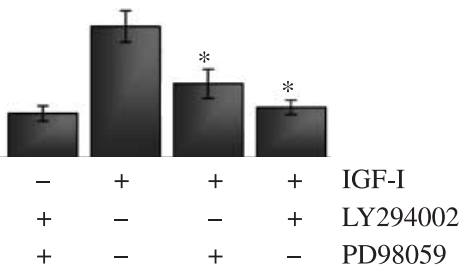

C

IGFBP-5 mRNA

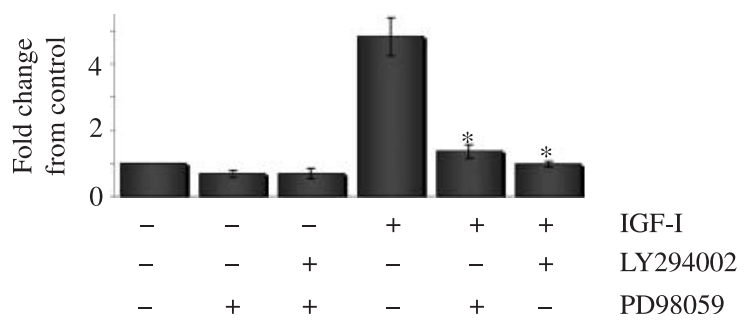

Figure 8 Inhibition of the PI3K or MAPK pathway decreases the ability of IGF-I to regulate IGFBP-3 and -5 mRNA levels in primary mammary fibroblasts. Near confluent fibroblasts were incubated for $24 \mathrm{~h}$ in DMEM + 10\% charcoal stripped FBS, then serum starved for $24 \mathrm{~h}$, pretreated for $30 \mathrm{~min}$ with serum-free media \pm inhibitors (LY294002 and PD98059, $20 \mu \mathrm{M})$, and treated \pm IGF-I $(100 \mathrm{ng} / \mathrm{ml})$ for $5 \mathrm{~min}(\mathrm{~A})$ or $8 \mathrm{~h}(\mathrm{~B})$. (A) Total cell lysates $(20 \mu \mathrm{g})$ were resolved by SDS-PAGE and immunoblotted with antibodies specific for phosphorylated AKT or ERK 1/2. Membranes were stripped and re-probed with antibodies that detect total AKT or ERK 1/2. Representative blots of at least three separate experiments are shown. (B) Total RNA was isolated and analyzed by northern blotting by hybridizing with ${ }^{32} \mathrm{P}$-labeled bovine IGFBP-3, human IGFBP-5 and 18S cDNA. Relative intensity by Phosphorlmager analysis: data represent mean \pm s.E.M. of at least four separate experiments. ${ }^{*}$ Indicates significant decrease from IGF-I $(P<0 \cdot 002)$.

In contrast to MAC-T cells, treatment with IGF-I activated both the PI3K and the MAPK pathways in these cells (Fig. 9A). IGF-I-stimulated activation of the PI3K pathway began as early as $1 \mathrm{~min}$ and was sustained through $30 \mathrm{~min}$. 
A

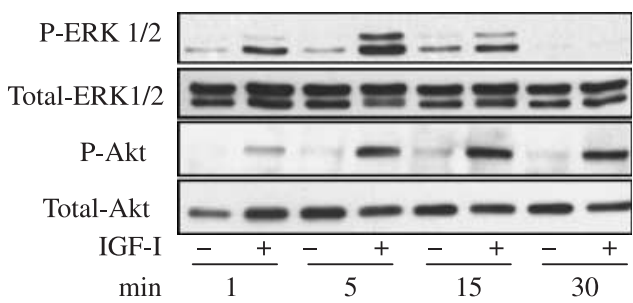

B

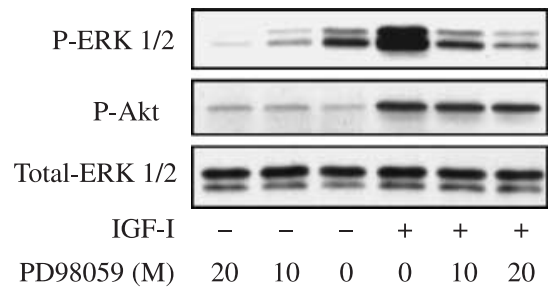

Figure 9 IGF-I stimulation induces activation of the PI3K and MAPK pathways in murine mammary epithelial cells. Near confluent cells were serum starved for $24 \mathrm{~h}$ prior to replacement with serum-free media \pm IGF-I $(100 \mathrm{ng} / \mathrm{ml})$ for the indicated times (A) or media were replaced with serum-free media \pm PD98059 for 30 min prior to $5 \mathrm{~min} \pm$ IGF-I $(100 \mathrm{ng} / \mathrm{ml})$ stimulation (B). Cell lysates $(25 \mu \mathrm{g})$ were resolved by SDS-PAGE and immunoblotted with antibodies specific for phosphorylated Akt or ERK 1/2. Membranes were stripped and re-probed with antibodies that detect total Akt or ERK 1/2. Figure shows representative immunoblots of at least three separate experiments.

The MAPK pathway was similarly activated by IGF-I, however, activation was transient and began to decrease after 5 min of treatment (Fig. 9A). Treatment with PD $(20 \mu \mathrm{M})$ was sufficient to inhibit the ability of IGF-I to stimulate the phosphorylation of ERK 1/2, and had no effect on the PI3K pathway (Fig. 9B).

We next examined the regulation of IGFBP-3 and -5 by IGF-I and the MAPK pathway in NMuMG cells. Basal levels of IGFBP-3 and -5 mRNA were readily detectable by northern blot analysis (data not shown) and were increased upon stimulation by IGF-I (Fig. 10). The pattern of regulation between the two IGFBP was similar to IGF-I treatment in MAC-T cells, i.e. IGF-I significantly increased IGFBP-3 levels approximately threefold above serum-free controls, while only slightly increasing IGFBP-5. Treatment with the MAPK inhibitor also slightly increased basal IGFBP-5 mRNA levels. Similar to MAC-T cells, treatment of NMuMG cells with IGF-I in the presence of a MAPK inhibitor significantly increased IGFBP-5 mRNA levels above increases observed with either treatment alone.

\section{Inhibition of the MAPK pathway induces apoptosis in MEC}

IGFBP-5 is frequently reported to be associated with cell death and apoptosis in the mammary gland (Flint et al. 2005). Therefore, we determined whether the treatments that significantly increased IGFBP-5 would affect the cell viability. MAC-T cells were treated with the MAPK inhibitor \pm IGF-I
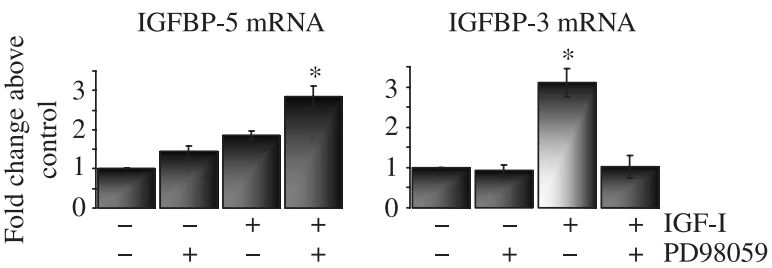

Figure 10 Inhibition of the MAPK pathway alters basal and IGF-Istimulated IGFBP-3 and -5 mRNA levels in murine mammary epithelial cells. Confluent cells were serum starved for $24 \mathrm{~h}$, pretreated for $30 \mathrm{~min}$ in serum-free media with a specific MAPK inhibitor, PD98059 $(20 \mu \mathrm{M})$, then exposed to \pm IGF-I $(100 \mathrm{ng} / \mathrm{ml})$ for $4 \mathrm{~h}$. Total RNA was isolated and analyzed by quantitative RT PCR as described in Material and Methods. Bars represent fold-increase over serum-free controls; data are mean \pm S.E.M. of three separate experiments. ${ }^{*}$ Indicates significant increase from serum-free controls $(P<0 \cdot 05)$.

for 6,12 , and $48 \mathrm{~h}$. Inhibition of the MAPK pathway induced apoptosis within $6 \mathrm{~h}$, and the extent of cell death increased over time. At each time point, IGF-I was able to significantly decrease PD-induced cell death $(P<0 \cdot 001)$. However, IGF-I was not able to completely rescue cells at 12 and $48 \mathrm{~h}$, as cell death was greater in IGF + PD-treated cells when compared with cells stimulated with IGF-I alone $(P<0 \cdot 03$; Fig. 11A).

To determine if the decreased ability of IGF-I to protect cells from PD-induced cell death involved binding to IGFBP

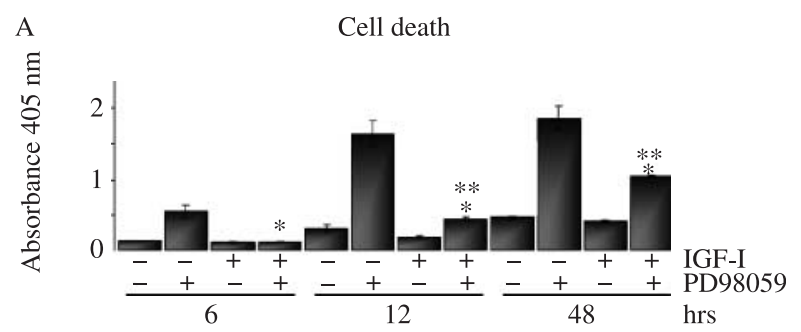

B

$48 \mathrm{~h}$

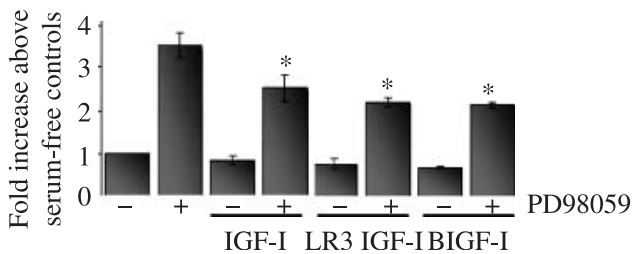

Figure 11 Treatment with IGF-I rescues cells from death induced by the inhibition of the MAPK pathway in MAC-T cells. Confluent cells were serum starved for $24 \mathrm{~h}$, pretreated for $30 \mathrm{~min}$ in serum-free media \pm the specific MAPK inhibitor, PD98059 $(20 \mu \mathrm{M})$, then exposed to (A) \pm IGF-I $(100 \mathrm{ng} / \mathrm{ml})$ for the indicated times or $(\mathrm{B}) \pm$ IGF-I, LongR3 IGF-I (LR3) or B-Chain IGF-I (B IGF-I; $100 \mathrm{ng} / \mathrm{ml}$ ) for $48 \mathrm{~h}$. Cell death was determined by the Roche Cell Death ELISA ${ }^{\text {plus }}$ kit according to manufacturer's instructions. Each bar represents the mean \pm S.E.M. of at least four individual experiments with each treatment performed in triplicate within an experiment. For a given time point, *indicates significant decrease from PD98059 treatment alone $(P<0 \cdot 001) ; * *$ indicates significant increase from IGF-I treatment $(P<0 \cdot 03)$. 
in the extracellular environment, experiments were performed with mutated IGF-I ligands that exhibit reduced affinity for IGFBP (Fig. 11B). The inhibition of PD-induced cell death was similar regardless of the IGF ligand tested.

\section{Discussion}

In the present study, we show that the MAPK pathway tonically repressed both basal as well as IGF-I-stimulated IGFBP-5 expression in both bovine and murine MEC. This regulation was specific for the MAPK pathway, as inhibiting the PI3K pathway had the opposite effect.

The role of the PI3K and MAPK pathways in the regulation of IGFBP-3 and -5 has been investigated in cells derived from other tissues. In growth plate chondrocytes, vascular smooth muscle cells, and primary Schwann cells, stimulation of IGFBP-5 mRNA expression by IGF-I was shown to be mediated exclusively via the PI3K pathway (Cheng et al. 1999, Duan et al. 1999, Kiepe et al. 2005). In contrast to these studies, in rat intestinal smooth muscle cells, IGF-I-mediated IGFBP-5 expression was mediated exclusively via the MAPK pathway (Xin et al. 2004). Similar to our observation in MF, the enhancement of IGFBP-5 mRNA expression by IGF-I was mediated via both the MAPK and the PI3K pathways in human intestinal smooth muscle cells (Kuemmerle 2000). Additionally, in the present study, both the PI3K and the MAPK pathways were required for the regulation of IGFBP-3 expression by IGF-I in both MEC and MF. Similar results have been reported in growth plate chondrocytes and human intestinal smooth muscle cells (Kuemmerle 2000, Kiepe et al. 2005). However, to the best of our knowledge, this is the first report to show that an intracellular signaling pathway represses the ability of IGF-I to increase an IGFBP.

Numerous studies have shown a positive relationship between IGFBP-5 and involution in the mammary gland. Studies with STAT3 knockout mice demonstrated a delay in involution and a reduction in IGFBP-5, while the interferon regulatory factor-1 knockout mice exhibited enhanced IGFBP-5 expression as well as enhanced involution (Chapman et al. 2000a,b). Moreover, the DNA content in the mammary glands of transgenic mice overexpressing IGFBP-5 was decreased as early as day 10 of pregnancy and mammary cell number and milk synthesis were both decreased by $\sim 50 \%$ during the first 10 days of lactation (Flint et al. 2005). The concentration of the pro-apoptotic molecule caspase-3 was increased in the transgenic mice, whilst the concentrations of the pro-survival molecules Bcl-2 and $\mathrm{Bcl}-\mathrm{x}$ were decreased, as was IGF-I receptor and Akt phosphorylation. This suggests that IGFBP-5 was, in part, enhancing apoptosis by inhibiting the pro-survival effects of IGF-I. Interestingly, in the present study, inhibition of the MAPK pathway induced apoptosis in MAC-T cells. While IGF-I was able to rescue cells from cell death, its ability to do so was attenuated at later time points. This did not appear to be related to inhibition of IGF-I activity by IGFBPs in the extracellular environment, since similar effects were observed with IGF-I analogs with reduced affinity for IGFBP. The finding that IGFBP-5 expression was the only IGFBP increased in the presence of PD fits with a role for IGFBP-5 in cell death. Future studies using small interfering RNA approaches are needed to directly elucidate the specific physiological roles of IGFBP-5 in MEC.

In support of a physiological relevance to our finding, ERK was shown to be rapidly de-phosphorylated during early stages of murine mammary involution in vivo (Kritikou et al. 2003). Moreover, an in vivo comparison between the phosphorylation levels of intracellular signaling molecules in lactating and involuting wild-type mammary glands demonstrated that, while the phosphorylated level of $\mathrm{AKT}^{\text {Ser473 }}$ remained similar during lactation and involution, involuting glands had substantially reduced ERK phosphorylation when compared with those during lactation (Faraldo et al. 2001). Although the mechanism of altered MAPK/ERK signaling has not been established, this may be directly related to the in vivo increases observed in IGFBP-5 at the onset of involution. Furthermore, since IGFBP-5 is distinctly upregulated during both differentiation and involution of MEC (Lochrie et al. 2006), alterations in the phosphorylation of MAPK represents a unique mechanism for cellular control of IGFBP-5 production. Indeed, there are numerous negative regulators of the MAPK pathway including phosphatases and scaffolding proteins (Morrison \& Davis 2003, Sebolt-Leopold \& Herrera 2004). For example, activation of the MAPK phosphatases (MKP-1 and MKP-3) specifically inactivates ERK 1/2 (Farooq \& Zhou 2004), and the protein Ras-interacting protein-1 competes with Raf for binding to Ras thereby blocking MAPK (ERK1/2) activation (Wang et al. 2002). Additionally, the protein impedes mitogenic signal propagation (IMP) blocks the functional assembly of MEK and Raf kinases through kinase suppressor of Ras (KSR; Matheny et al. 2004).

In the present study, IGFBP-5 was detected in conditioned media by ligand blot analysis from cells treated with IGF-I and IGF-I plus PD, but not from cells treated with PD alone, even though it stimulated similar increases in IGFBP-5 mRNA when compared with IGF-I. Several studies have shown that IGFBP-5 may mediate its effects, in part, through IGF-independent effects involving extracellular matrix interactions and tissue remodeling (Flint et al. 2000, 2005, Tonner et al. 2000, 2002). IGFBP-5 is capable of binding to the cell surface and extracellular matrix molecules, as well as as2-casein and plasminogen activator inhibitor-1 (Sorrell et al. 2006). Furthermore, it was demonstrated that IGF-I and -II could displace endogenous IGFBP-5 from monolayers of the murine MEC line HC11 (Beattie et al. 2005). Therefore, we hypothesize that IGFBP-5 may be binding to the ECM or cell surface in the absence of IGF-I. Alternatively, there may be an IGF-dependent mechanism required for IGFBP-5 to be secreted from the cell. The possibility also exists that the IGFBP-5 produced when the MAPK pathway is inhibited 
undergoes proteolytic degradation in the absence of IGF-I. We are currently investigating the potential mechanisms that underlie this interesting observation.

In addition to extracellular roles for IGFBP-5, new data have emerged identifying IGFBP-5 as a unique intracellular regulator of cell function. IGFBP-5 contains a nuclear localization sequence and a recent study has provided new experimental evidence for the nuclear presence of endogenous IGFBP-5 in mouse embryos in vivo (Zhao et al. 2006). This report was the first to demonstrate nuclear localization of IGFBP-5 under a physiological context, and in this study, IGFBP-5 was shown to have a functional trans-activation domain that interacted with histone/DNA complexes (Zhao et al. 2006). Given the rapid increase in IGFBP-5 mRNA levels, observed within $1 \mathrm{~h}$ of IGF-I-stimulation and inhibition of the MAPK pathway, there is a possibility that IGFBP-5 is playing an intracellular role in MEC. Further studies analyzing the mechanisms involved in IGFBP-5 regulation will help decipher both its extra- and intracellular functions.

\section{Funding}

This project was supported by National Research Initiative Competitive Grant Number 2003-35206-12811 from the USDA Cooperative State Research, Education and Extension Service and Hatch Project Number NJ06148 from the New Jersey Agricultural Experiment Station at Rutgers, The State University of New Jersey. All authors have no conflict of interest to declare.

\section{References}

Allar MA \& Wood TL 2004 Expression of the insulin-like growth factor binding proteins during postnatal development of the murine mammary gland. Endocrinology 145 2467-2477.

Beattie J, Phillips K, Shand JH, Szymanowska M, Flint DJ \& Allan GJ 2005 Molecular recognition characteristics in the insulin-like growth factor (IGF)-insulin-like growth factor binding protein -3/5 (IGFBP-3/5) heparin axis. Journal of Molecular Endocrinology 34 163-175.

Boutinaud M, Shand JH, Park MA, Phillips K, Beattie J, Flint DJ \& Allan GJ 2004 A quantitative RT-PCR, study of the mRNA expression profile of the IGF axis during mammary gland development. Journal of Molecular Endocrinology 33 195-207.

Chapman RS, Duff EK, Lourenco PC, Tonner E, Flint DJ, Clarke AR \& Watson CJ 2000a A novel role for IRF-1 as a suppressor of apoptosis. Oncogene 19 6386-6391.

Chapman RS, Lourenco P, Tonner E, Flint D, Selbert S, Takeda K, Akira S, Clarke AR \& Watson CJ $2000 b$ The role of Stat 3 in apoptosis and mammary gland involution. Conditional deletion of Stat3. Advances in Experimental Medicine and Biology 480 129-138.

Cheng HL, Shy M \& Feldman EL 1999 Regulation of insulin-like growth factor-binding protein-5 expression during Schwann cell differentiation. Endocrinology 140 4478-4485.

Cohick WS \& Turner J 1998 Regulation of insulin-like growth factor binding protein synthesis by a bovine mammary epithelial cell line. Journal of Endocrinology 157 327-336.
Cohick WS, Wang B, Verma P \& Boisclair YR 2000 Insulin-like growth factor I (IGF-I) and cyclic adenosine $3^{\prime}, 5^{\prime}$ - monophosphate regulate IGF-binding protein-3 gene expression by transcriptional and posttranscriptional mechanisms in mammary epithelial cells. Endocrinology 141 4583-4591.

Duan C, Liimatta MB \& Bottum OL 1999 Insulin-like growth factor (IGF)-I regulates IGF-binding protein-5 gene expression through the phosphatidylinositol 3-kinase, protein kinase B/Akt, and p70 S6 kinase signaling pathway. Journal of Biological Chemistry 274 37147-37153.

Faraldo MM, Deugnier MA, Thiery JP \& Glukhova MA 2001 Growth defects induced by perturbation of $\beta 1$-integrin function in the mammary gland epithelium result from a lack of MAPK activation via the Shc and Akt pathways. EMBO Reports 2 431-437.

Farooq A \& Zhou MM 2004 Structure and regulation of MAPK phosphatases. Cellular Signalling 16 769-779.

Fleming JM, Leibowitz BJ, Kerr DE \& Cohick WS 2005 IGF-I differentially regulates IGF-binding protein expression in primary mammary fibroblasts and epithelial cells. Journal of Endocrinology 186 165-178.

Flint DJ, Tonner E \& Allan GJ 2000 Insulin-like growth factor binding proteins: IGF-dependent and -independent effects in the mammary gland. Journal of Mammary Gland Biology and Neoplasia 5 65-73.

Flint DJ, Boutinaud M, Tonner E, Wilde CJ, Hurley W, Accorsi PA, Kolb AF, Whitelaw CB, Beattie J \& Allan GJ 2005 Insulin-like growth factor binding proteins initiate cell death and extracellular matrix remodeling in the mammary gland. Domestic Animal Endocrinology 29 274-282.

Grill CJ, Sivaprasad U \& Cohick WS 2002 Constitutive expression of IGF-binding protein-3 by mammary epithelial cells alters signaling through Akt and p70S6 kinase. Journal of Molecular Endocrinology 29 153-162.

Huynh HT, Robitaille G \& Turner JD 1991 Establishment of bovine mammary epithelial cells (MAC-T): an in vitro model for bovine lactation. Experimental Cell Research 197 191-199.

Kiepe D, Ciarmatori S, Hoeflich A, Wolf E \& Tonshoff B 2005 Insulin-like growth factor (IGF)-I stimulates cell proliferation and induces IGF binding protein (IGFBP)-3 and IGFBP-5 gene expression in cultured growth plate chondrocytes via distinct signaling pathways. Endocrinology 146 3096-3104.

Kritikou EA, Sharkey A, Abell K, Came PJ, Anderson E, Clarkson RW \& Watson CJ 2003 A dual, non-redundant, role for LIF as a regulator of development and STAT3-mediated cell death in mammary gland. Development 130 3459-3468.

Kuemmerle JF 2000 Endogenous IGF-I, regulates IGF, binding protein production in human intestinal smooth muscle cells. American Journal of Physiology. Gastrointestinal and Liver Physiology 278 G710-G717.

Lochrie JD, Phillips K, Tonner E, Flint DJ, Allan GJ, Price NC \& Beattie J 2006 Insulin-like growth factor binding protein (IGFBP)-5 is upregulated during both differentiation and apoptosis in primary cultures of mouse mammary epithelial cells. Journal of Cellular Physiology 207 471-479.

Matheny SA, Chen C, Kortum RL, Razidlo GL, Lewis RE \& White MA 2004 Ras regulates assembly of mitogenic signalling complexes through the effector protein IMP. Nature 427 256-260.

Morrison DK \& Davis RJ 2003 Regulation of MAP kinase signaling modules by scaffold proteins in mammals. Annual Review of Cell and Developmental Biology 19 91-118.

Phillips K, Park MA, Quarrie LH, Boutinaud M, Lochrie JD, Flint DJ, Allan GJ \& Beattie J 2003 Hormonal control of IGF-binding protein (IGFBP)-5 and IGFBP-2 secretion during differentiation of the HC11 mouse mammary epithelial cell line. Journal of Molecular Endocrinology 31 197-208.

Plath-Gabler A, Gabler C, Sinowatz F, Berisha B \& Schams D 2001 The expression of the IGF family and GH receptor in the bovine mammary gland. Journal of Endocrinology 168 39-48.

Sebolt-Leopold JS \& Herrera R 2004 Targeting the mitogen-activated protein kinase cascade to treat cancer. Nature Reviews. Cancer 4 937-947.

Sivaprasad U, Fleming J, Verma PS, Hogan KA, Desury G \& Cohick WS 2004 Stimulation of insulin-like growth factor (IGF) binding protein-3 synthesis by IGF-I and transforming growth factor- $\alpha$ is mediated by both phosphatidylinositol-3 kinase and mitogen-activated protein kinase pathways in mammary epithelial cells. Endocrinology 145 4213-4221.

Sorrell AM, Shand JH, Tonner E, Gamberoni M, Accorsi PA, Beattie J, Allan GJ \& Flint DJ 2006 Insulin-like growth factor binding protein-5 
activates plasminogen by interaction with tissue plasminogen activator, independently of its ability to bind to plasminogen activator inhibitor-1, insulin-like growth factor-I or heparin. Journal of Biological Chemistry 281 10883-10889.

Tonner E, Quarrie L, Travers M, Barber M, Logan A, Wilde C \& Flint D 1995 Does an IGF-binding protein (IGFBP) present in involuting rat mammary gland regulate apoptosis? Progress in Growth Factor Research 6 409-414.

Tonner E, Barber MC, Travers MT, Logan A \& Flint DJ 1997 Hormonal control of insulin-like growth factor-binding protein-5 production in the involuting mammary gland of the rat. Endocrinology 138 5101-5107.

Tonner E, Allan G, Shkreta L, Webster J, Whitelaw CB \& Flint DJ 2000 Insulin-like growth factor binding protein-5 (IGFBP-5) potentially regulates programmed cell death and plasminogen activation in the mammary gland. Advances in Experimental Medicine and Biology 480 45-53.

Tonner E, Barber MC, Allan GJ, Beattie J, Webster J, Whitelaw CB \& Flint DJ 2002 Insulin-like growth factor binding protein-5 (IGFBP-5) induces premature cell death in the mammary glands of transgenic mice. Development 129 4547-4557.

Voge JL, Santiago CA, Aad PY, Goad DW, Malayer JR \& Spicer LJ 2004 Quantification of insulin-like growth factor binding protein mRNA using real-time PCR in bovine granulosa and theca cells: effect of estradiol, insulin, and gonadotropins. Domestic Animal Endocrinology 26 241-258.
Wang Y, Waldron RT, Dhaka A, Patel A, Riley MM, Rozengurt E \& Colicelli J 2002 The RAS effector RIN1 directly competes with RAF and is regulated by 14-3-3 proteins. Molecular and Cellular Biology 22 916-926.

Wood TL, Richert MM, Stull MA \& Allar MA 2000 The insulin-like growth factors (IGFs) and IGF binding proteins in postnatal development of murine mammary glands. Journal of Mammary Gland Biology and Neoplasia 5 31-42.

Xin X, Hou YT, Li L, Schmiedlin-Ren P, Christman GM, Cheng HL, Bitar KN \& Zimmermann EM 2004 IGF-I, increases IGFBP-5 and collagen $\alpha 1$ (I) mRNAs by the MAPK pathway in rat intestinal smooth muscle cells. American Journal of Physiology. Gastrointestinal and Liver Physiology 286 G777-G783.

Zhao Y, Yin P, Bach LA \& Duan C 2006 Several acidic amino acids in the $\mathrm{N}$-domain of insulin-like growth factor binding protein (IGFBP)-5 are important for its transactivation activity. Journal of Biological Chemistry 281 14181-14191.

Received in final form 23 May 2007

Accepted 29 May 2007

Made available online as an Accepted Preprint

1 June 2007 